\title{
Gut microbiota of the threatened takahè: biogeographic patterns and conservation implications
}

Annie G. West ${ }^{1}$ (D), Anne DeLaunay ${ }^{1}$, Phil Marsh², Elena K. Perry ${ }^{1,5}$, Megan Jolly ${ }^{3}$, Brett D. Gartrell ${ }^{3}$, An Pas $^{4}$, Andrew Digby ${ }^{2}$ and Michael W. Taylor ${ }^{1 *}$

\begin{abstract}
Background: The Aotearoa New Zealand takahē (Porphyrio hochstetteri), once thought to be extinct, is a nationally threatened flightless rail under intensive conservation management. While there has been previous research into disease-related microbes in takahē, little is known about the microbes present in the gastrointestinal tract. Given the importance of gut-associated microbes to herbivore nutrition and immunity, knowledge of these communities is likely to be of considerable conservation value. Here we examined the gut microbiotas of 57 takahe at eight separate locations across Aotearoa New Zealand.

Results: Faecal samples, taken as a proxy for the hindgut bacterial community, were subjected to 16S rRNA gene amplicon sequencing using Illumina MiSeq. Phylogenetic analysis of > 2200 amplicon sequence variants (ASVs) revealed nine main bacterial phyla (Acidobacteriota, Actinobacteriota, Bacteroidota, Campilobacterota, Firmicutes, Fusobacteriota, Planctomycetota, Proteobacteria, and Verrucomicrobiota) that accounted for the majority of sequence reads. Location was a significant effect ( $p$ value $<0.001,9999$ permutations) that accounted for $32 \%$ of the observed microbiota variation. One ASV, classified as Lactobacillus aviarius, was present in all samples at an average relative abundance of $17 \%(S D=23.20)$. There was strong evidence $(p=0.002)$ for a difference in the abundance of the genus Lactobacillus between locations. A common commensal bacterium previously described in takahē, Campylobacter spp., was also detected in most faecal samples.
\end{abstract}

Conclusions: Location plays a pivotal role in the observed variation among takahē gut bacterial communities and is potentially due to factors such as supplemental feeding and medical treatment experienced by birds housed in captivity at one of the eight sampled sites. These data present a first glimpse of the previously unexplored takahē gut microbiota and provide a baseline for future microbiological studies and conservation efforts.

Keywords: Microbiome, Endangered, Bird, Avian, Conservation, Microbiota

\section{Introduction}

The takahe (Porphyrio hochstetteri) is a threatened, flightless species of rail endemic to Aotearoa New Zealand. After being declared extinct in 1898 , a small population

*Correspondence: mw.taylor@auckland.ac.nz

1 School of Biological Sciences, University of Auckland, Private Bag 92019, Auckland 1142, New Zealand

Full list of author information is available at the end of the article was rediscovered in a remote mountain range of the southern Te Waipounamu South Island 50 years later. Takahē, the largest member of the Rallidae family, were once widespread across numerous edge-type habitats, but have since taken refuge in alpine grass habitats due to climate change, habitat loss, and the arrival of humans and introduced mammalian predators [12, 25, 40,65]. Population numbers have fluctuated since rediscovery due to predation by stoats and competition with deer for 
food [28, 40, 45, 76]. Several breeding programmes and insurance populations were therefore established to safeguard against drastic reductions in takahē numbers [13]. After decades of dedicated conservation efforts the population has now reached $>400$ individuals and additional suitable habitats are being identified to house the growing number of takahē. There are currently well-established research initiatives regarding takahē nutrition, health and breeding, and genome sequencing. However, an important aspect of takahē biology that remains understudied is the role of symbiont microbiota in takahē gut health and immunity.

The key roles of gut microbes in host digestion, nutrition and immunity are now widely recognised (reviewed by Spor et al. [61], Hall et al. [26] and Gilbert et al. [17]). Although birds constitute the largest class of tetrapods, avian microbiota studies remain largely outnumbered by those of the mammalian microbiota. Here, we use the term 'microbiota' to refer to a community of microorganisms present in a defined environment (e.g. the gut), while the term 'microbiome' encompasses the microbiota as well as their theatre of activity, i.e. genomic structures and elements, metabolites and surrounding environmental conditions [7, 38]. Some existing avian-related studies have focused on digestive capabilities, such as in the foregut-fermenting hoatzin $[19,20]$, or were conducted within the scope of conservation management programmes, including the critically endangered kākāpō (Strigops habroptilus) [49, 67], northern bald ibis (Geronticus eremita) [60] and two Old World vultures, the Griffon (Gyps fulvus) and Egyptian vulture (Neophron percnopterus) [5]. However, most studies of the avian microbiota are concentrated on commercially farmed species (e.g. broiler chicken Gallus gallus domesticus, turkey Meleagris gallopavo domesticus, ostrich Struthio camelus) and aim to understand how beneficial microbes may influence animal growth, fitness, and reproduction $[24,68,70]$. While the exact relationship between the microbiota and host fitness remains unclear, gut microbes are indeed essential to the digestion of complex plant polysaccharides and to host resilience against invading pathogens. Herbivores rely on microorganisms in the gut to break down fibrous plant material and convert these complex molecules to more easily digestible short-chain fatty acids (SCFA) [30, 37].

Takahē are near-exclusive herbivores that feed predominantly on Chionochloa tussock meristems, tikumu mountain daisy (Celmisia petrieiv) and huarau fern (Hypolepis millefolium) rhizomes in their native habitat, supplemented by the occasional invertebrate [, 34, 47, 54, 79] and producing a staggering $9 \mathrm{~m}$ of largely undigested, grassy stool each day [27, 34, 54]. Takahē likely support a form of fermentation in a pair of slightly elongated, simple caeca where some plant matter is diverted, but this represents a very small proportion of the ingested material [27, 62]. Dietary habits are likely to differ significantly among takahē populations, especially in sanctuaries that incorporate supplemental feeding schemes to support breeding pairs (all locations that provide supplementary feed use the same cereal-based pellet).

Significant changes in gut microbiota composition have been observed for threatened species housed in captive environments and/or undergoing medical treatment [42, $74]$. The potential for captive animals to lose key components of the microbiota that are essential to digestion and host function in the wild is concerning and could in some cases result simply from insufficient variation in the diet. Loss of key microbial players could impact nutritional efficiency and functional capacity of the gut microbiota, particularly in herbivorous animals where some microbes play important roles in degrading toxic plant compounds (xenobiotics) $[1,2,9,16]$. Changes to the gut microbiota that impact host health could also lower the efficacy of breeding and translocation programmes.

Given the importance of the gut microbiota to host health, particularly in herbivore digestion and nutrition, baseline knowledge of key microbial taxa in the takahē gut microbiota would add greatly to our knowledge of takahē biology. Existing microbiology-based research in takahē has focused solely on specific microbial taxa such as Campylobacter $[22,23]$, which has been identified as a common commensal bacterium in takahē faecal material, and the potential for pathogen transmission among subpopulations with regular translocations [21]. The primary aim of this present study was to characterise the bacterial community colonising the gut of adult takahē from different geographic locations using faecal samples as a proxy for gut microbial assemblages [66]. It represents an initial investigation into the takahē gut microbiota that should ultimately facilitate finer-scale studies which aid in managing the health and conservation of this rare, enigmatic bird.

\section{Materials and methods \\ Sample collection}

Fresh or recently deposited $(<1 \mathrm{~h})$ faecal material collected from 57 adult takahē (representing $14 \%$ of the global population at the time of sampling) between August 2016 and June 2017 (see Additional file 1) by MJ and New Zealand Department of Conservation (Te Papa Atawhai; NZDOC) staff was placed directly into $15 \mathrm{~mL}$ sterile polypropylene tubes containing RNAlater (for ease of transport and use in remote field locations; [59]), then stored overnight at $4{ }^{\circ} \mathrm{C}$ followed by subsequent storage at $-20^{\circ} \mathrm{C}$. The faecal material was obtained from takahē residing in sanctuary sites and from the sole 
wild population at the time of sampling, totalling eight separate sampling locations across Aotearoa New Zealand: Burwood Takahē Centre (Te Anau), Cape Sanctuary (Te Kauwae-a-Māui Peninsula, $39^{\circ} 38^{\prime} \mathrm{S}, 177^{\circ} 05^{\prime} \mathrm{E}$ ), Mana Island (Kapiti Coast, $41^{\circ} 05^{\prime} \mathrm{S}, 174^{\circ} 46^{\prime} \mathrm{E}$ ), Motutapu Island (Hauraki Gulf, $36^{\circ} 45^{\prime} \mathrm{S}, 174^{\circ} 54^{\prime} \mathrm{E}$ ), Te Puhia-Noa Murchison Mountain Range (wild population; "Murchison Mountains", 45 $15^{\circ} \mathrm{S}, 167^{\circ} 32^{\prime}$ E), Rotoroa Island (Hauraki Gulf, $36^{\circ} 49^{\prime} \mathrm{S}, 175^{\circ} 12^{\prime} \mathrm{E}$ ), an island in the Foveaux Strait (Te Ara-a-Kewa), and Tiritiri Matangi Island (Hauraki Gulf, $36^{\circ} 36^{\prime} \mathrm{S}, 174^{\circ} 53^{\prime}$ E). Samples were shipped to the Waipapa Taumata Rau University of Auckland on ice for DNA extraction and sequencing and were stored on arrival at $-20{ }^{\circ} \mathrm{C}$. Metadata for this study included takahē age, sex, supplemental feeding regime, puppet vs wild rearing, location, nest site, hatch site, and habitat type (regenerating vs established) (metadata table included as Additional file 1). Burwood Takahē Centre houses a captive breeding population with intensive anthropogenic management, while the other subpopulations at Cape Sanctuary, Rotoroa Island, Mana Island, Tiritiri Matangi Island, Motutapu Island, and the Foveaux Strait island represent insurance populations that also experience regular anthropogenic management. The wild, free-to-roam population is largely left alone with little to no anthropogenic interference. Supplementary feed consists of a cereal-based pelleted ration that is the same for all locations. Locations where takahe are regularly provided supplementary feed (at least once per week) include Burwood Takahē Centre, Cape Sanctuary, Rotoroa Island, Mana Island and Tiritiri Matangi Island. Occasional supplementary feeding (once per fortnight or less) is provided at Motutapu Island, while no supplemental feed is provided to the wild Te Puhi-a-Noa Murchison Mountain population or to the takahē on the Foveaux Strait island.

Faecal samples are often collected as part of routine management of takahē. Samples collected for this study were approved by NZDOC and did not require ethics approval from NZDOC Animal Ethics Committee, which upholds NZDOC's obligations under the New Zealand Animal Welfare Act.

\section{DNA extraction, PCR and 16S rRNA gene sequencing}

Total DNA was extracted from thawed samples using a bead-beating method previously described by Perry et al. [49]. In brief, $100 \mathrm{mg}$ of faecal material was washed twice with $70 \%$ ethanol before suspension in a high-salt, CTAB-based extraction buffer, followed by agitation in a FastPrep FP120 bead beater at $5.5 \mathrm{~ms}^{-1}$ for $30 \mathrm{~s}$. Samples were then repeatedly incubated at $65{ }^{\circ} \mathrm{C}$, cleaned with a 24:1 chloroform/isoamyl alcohol mix and incubated overnight twice at $-20{ }^{\circ} \mathrm{C}$ with $0.6 \mathrm{vol}$ isopropanol and 0.1 vol sodium acetate ( $3 \mathrm{M}, \mathrm{pH} 5.2$ ), followed by two rounds of ethanol wash. The final pellet was suspended in $20 \mu \mathrm{L}$ of $10 \mathrm{mM}$ Tris- $\mathrm{HCl}(\mathrm{pH}$ 8). The variable V3-V4 region of the 16S rRNA gene was amplified following Perry et al. [49], with PCR reactions performed in triplicate for each faecal sample then pooled to increase DNA yield. A KAPA 3G Plant PCR kit was used for amplification with initial denaturation at $95^{\circ} \mathrm{C}$ for $3 \mathrm{~min}$, followed by 35 cycles of denaturation at $95^{\circ} \mathrm{C}$ for $20 \mathrm{~s}$, annealing at $57^{\circ} \mathrm{C}$ for $15 \mathrm{~s}$, and extension at $72{ }^{\circ} \mathrm{C}$ for $30 \mathrm{~s}$. The final elongation was set at $72{ }^{\circ} \mathrm{C}$ for $1 \mathrm{~min}$. Amplicon size and the absence of a band for negative controls (including laboratory extraction controls and PCR amplification notemplate controls) were verified on a $1 \%$ agarose gel with SYBR Safe DNA Gel Stain (Invitrogen, New Zealand). PCR products were purified using AMPure XP (Beckman Coulter, New Zealand) beads and DNA concentration was quantified on a Qubit Fluorometer 1.0 (Invitrogen, New Zealand) using the High Sensitivity dsDNA kit. Samples were normalised to $10 \mathrm{ng} / \mu \mathrm{L}$ for library preparation and sequencing by New Zealand Genomics Ltd on an Illumina MiSeq with $2 \times 300$ bp chemistry.

\section{Sequence data analysis}

All raw paired-read 16S rRNA gene sequence data were analysed on the New Zealand eScience Infrastructure (NeSI) High Performance Computing cluster Mahuika in R (version 4.0.1 [51]) using the DADA2 software package (version 1.16 [10]). Primer regions were removed and forward and reverse reads subsequently truncated to $280 \mathrm{bp}$ and $240 \mathrm{bp}$, respectively. Sequence reads shorter than the truncated value were discarded, as were reads where trunc $\mathrm{Q}<2$ or where the number of expected errors exceeded 3 for forward and reverse reads $(-\operatorname{maxEE}$ parameter). The DADA2 error learning algorithm was then applied to the forward and reverse reads, which were subsequently dereplicated into unique sequences. The DADA2 core sample algorithm was applied to the dereplicated sequences, which were merged thereafter to obtain the full denoised sequence. Sequence chimeras were excluded and taxonomy assigned using the SILVA species version 138 ribosomal RNA reference database [50] (see Additional file 2 for taxonomic assignments of ASVs). A phylogenetic tree was constructed using the DECIPHER (version 2.16.1 [80]) and phangorn (version 2.5 .5 [58]) packages. Sequence files and metadata for all samples were uploaded to SRA under Bioproject number PRJNA737580.

The resulting ASV table (see Additional file 3 for nonrarefied ASV table), taxonomic assignments and phylogenetic tree were combined with corresponding metadata to construct a phyloseq object using the $\mathrm{R}$ (version 4.1.0 [52]) package phyloseq (version 1.34.0 [43]). Non-target 
sequences including chloroplasts and mitochondria were removed from the data set using phyloseq's prune_taxa function. The ASV table was also filtered to remove lowabundance ASVs (total relative abundance $<0.001 \%$ ) and ASVs not assigned to phylum level. The dataset was then rarefied to the minimum number of reads per sample (8000) to account for substantial differences in library size for subsequent analyses [73]. ASVs are numbered in decreasing order of their relative sequence abundance across the dataset.

To explore variation among bacterial communities grouped by significant covariates (beta-diversity), generalised UniFrac (GUniFrac version 1.1 [11]) and BrayCurtis (vegan) distances were calculated from the rarefied data and subjected to non-metric multidimensional scaling (nMDS) and principal coordinate analysis (PCoA) ordination (see Additional file 5: Figure S1 for gUniFrac PCoA visualisations). We tested for significant associations between dissimilarity matrices and corresponding covariates using the PERMANOVA adonis2 function of the vegan package with 9999 permutations. Significant PERMANOVA models were further subjected to pairwise comparison testing using the pairwise.adonis function of the pairwiseAdonis package (version 0.4 [39]). We subsequently used the vegan functions betadisper and permutest to test for homogeneous group dispersion.

Alpha-diversity indices were explored by applying phyloseq's estimate_richness function to the rarefied data. Associations between alpha-diversity indices and corresponding metadata (age, sex, supplemental feeding, rearing method, location, and habitat type) were tested using Kruskal-Wallis or ANOVA tests (dependent on Shapiro Wilks normality tests) using the vegan package (version 2.5-7 [48]). Post-hoc pairwise comparisons were performed for significant Kruskal-Wallis and ANOVA models using Dunn's test (dunn.test package version 1.3.5 [14]) with Benjamini-Hochberg $p$ value correction [6] or Tukey's HSD test (stats package version 4.1.0 [52]). The core microbiota was identified as those ASVs present in $70 \%$ of individuals at $>0.01 \%$ relative abundance and genera present in $75 \%$ of individuals at $>1 \%$ relative abundance using the package microbiome (version 1.13.9 [33]). The relative distribution of core genera within each location was plotted with associated Kruskal-Wallis tests for each taxon using a modified version of a script published on GitHub by Bodkhe et al. [8].

We then created a separate taxonomic level which concatenated genus-and species-level assignments together and agglomerated the phyloseq object to this taxonomy group. The plyr package (version 1.8.6 [75]) was leveraged to group less abundant ASVs into the category 'Others' based on a per-species mean relative abundance of $<0.3 \%$ and the data were plotted against location for all faecal samples. Finally, the DESeq2 package (version 1.30.0 [36]) was used to test for differential abundance of ASVs (test = "Wald", fitType = "local") between Te Puhia-Noa Murchison Mountain and Burwood Takahē Centre samples using the non-rarefied data (as described in [8]).

All data were visualised using the $\mathrm{R}$ packages ggplot2 (version 3.3.3 [77]), ggpubr (version 0.4.0 [31]), cowplot (version 1.1.1 [78]), ggsci (futurama palette, version 2.9 [81]) and Manu ('takahē' palette specifically designed on the colours of the takahē, version 0.0.1 [53, 63]).

The markdown file for all analyses is included as Additional file 4.

\section{Results}

In total, 7,877,544 raw $16 \mathrm{~S}$ rRNA gene sequence reads were obtained from the 57 takahē faecal samples, with 1,798,118 merged reads remaining after quality and chimera filtering. Following removal of non-target sequences and low-abundance ASVs, 2,224 unique ASVs were identified across the entire data set. The ASV table was rarefied to 8000 reads per sample for statistical analyses, which reduced the total number of ASVs to 2,222. The number of ASVs per sample ranged from 86 to 555 , with an average of 287 . Overall, $99.99 \%$ of filtered sequence reads could be assigned to at least phylum level.

Nine bacterial phyla each exceeded $0.1 \%$ mean relative sequence abundance (MRA) across the entire data set, namely Acidobacteriota (MRA $=2.90 \mathrm{e}^{-3} \pm \mathrm{SD}$ 0.02), Actinobacteriota (MRA $=0.04 \pm 0.05), \quad$ Bacteroidota $\quad(\mathrm{MRA}=0.20 \pm 0.20), \quad$ Campilobacterota $(\mathrm{MRA}=0.01 \pm 0.03), \quad$ Firmicutes $\quad(\mathrm{MRA}=0.52 \pm 0.25)$, Fusobacteriota $\quad(\mathrm{MRA}=0.04 \pm 0.11), \quad$ Planctomycetota $\quad\left(\mathrm{MRA}=1.35 \mathrm{e}^{-3} \pm 6.41 \mathrm{e}^{-3}\right), \quad$ Proteobacteria $(\mathrm{MRA}=0.17 \pm 0.18)$, and Verrucomicrobiota $\left(\mathrm{MRA}=1.78 \mathrm{e}^{-3} \pm 4.02 \mathrm{e}^{-3}\right)$ (Fig. 1A). Relative sequence abundances varied considerably among individual birds and locations. Firmicutes dominated the data set, accounting for $51.9 \%$ of rarefied reads. Bacteroidota and Proteobacteria accounted for the majority of remaining reads (19.98\% and $17.2 \%$ respectively), while Acidobacteriota, Actinobacteriota, Campilobacterota, Fusobacteriota, Planctomycetota and Verrucomicrobiota together comprised $10.6 \%$ of total sequence reads. The majority of rarefied and filtered ASVs were assigned a genus classification (96.5\%).

Within the Firmicutes phylum, Lactobacillus was by far the most numerous genus (Fig. 1B), followed by Clostridium sensu stricto 1, Turicibacter and Catellicoccus. Indeed, Lactobacillus was the most abundant bacterial genus overall, representing $23.6 \%$ of sequences that were assigned at genus level. Prevotella was the most abundant genus of the Bacteroidota phylum and the second most 


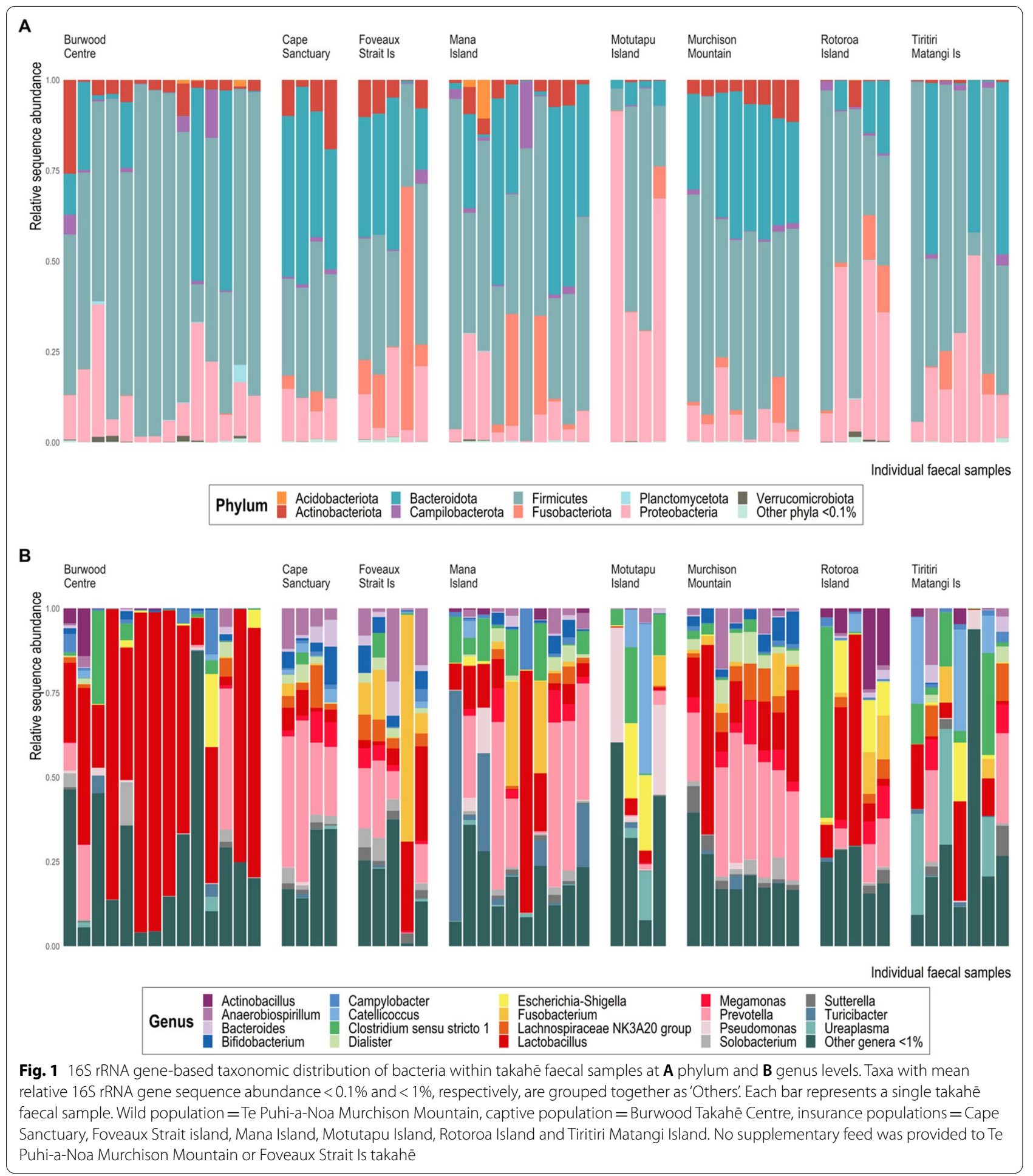

abundant taxon overall (14.3\% of all sequences assigned to genus). For Proteobacteria, the three most abundant genera were Anaerobiospirillum, Escherichia-Shigella, and Pseudomonas.
We observed a significant dispersion of bacterial communities by location ( $p$ value $<0.001$; Table 1$)$ with Bray-Curtis NMDS and gUniFrac PCoA ordinations (Fig. 2 and Additional file 5: Figure S1, respectively). Overall, location accounted for $32 \%$ of the observed 
Table 1 Statistical outputs for beta-diversity Bray-Curtis and gUniFrac matrices using PERMANOVA analyses performed with 9999 permutations

\begin{tabular}{|c|c|c|c|c|c|c|}
\hline \multirow[b]{2}{*}{ Covariate } & \multicolumn{3}{|c|}{ PERMANOVA for Bray-Curtis matrix } & \multicolumn{3}{|c|}{ PERMANOVA for gUniFrac matrix } \\
\hline & $p$ value & F-statistic & $\mathrm{R}^{2}$ & $p$ value & F-statistic & $\mathrm{R}^{2}$ \\
\hline Location & $<0.001^{* * *}$ & 3.27 & 0.32 & $<0.001^{* * *}$ & 3.36 & 0.32 \\
\hline Supplemental feeding & $<0.001^{* * *}$ & 3.37 & 0.11 & $<0.001^{* * *}$ & 3.92 & 0.13 \\
\hline Habitat type & $<0.001^{* * *}$ & 4.13 & 0.07 & $0.01^{*}$ & 3.11 & 0.05 \\
\hline Age & 0.64 & 0.80 & 0.02 & 0.94 & 0.46 & 0.008 \\
\hline Sex & 0.12 & 1.45 & 0.03 & 0.17 & 1.41 & 0.03 \\
\hline Hatch site & 0.06 & 1.23 & 0.21 & 0.15 & 1.19 & 0.21 \\
\hline Nest site & 0.06 & 1.23 & 0.21 & 0.15 & 1.86 & 0.21 \\
\hline Origin & 0.55 & 0.93 & 0.03 & 0.92 & 0.59 & 0.02 \\
\hline
\end{tabular}

Significant $p$ values are denoted with asterisks $\left(p<0.05={ }^{*}, p<0.01={ }^{* *}, p<0.001={ }^{* * *}\right)$

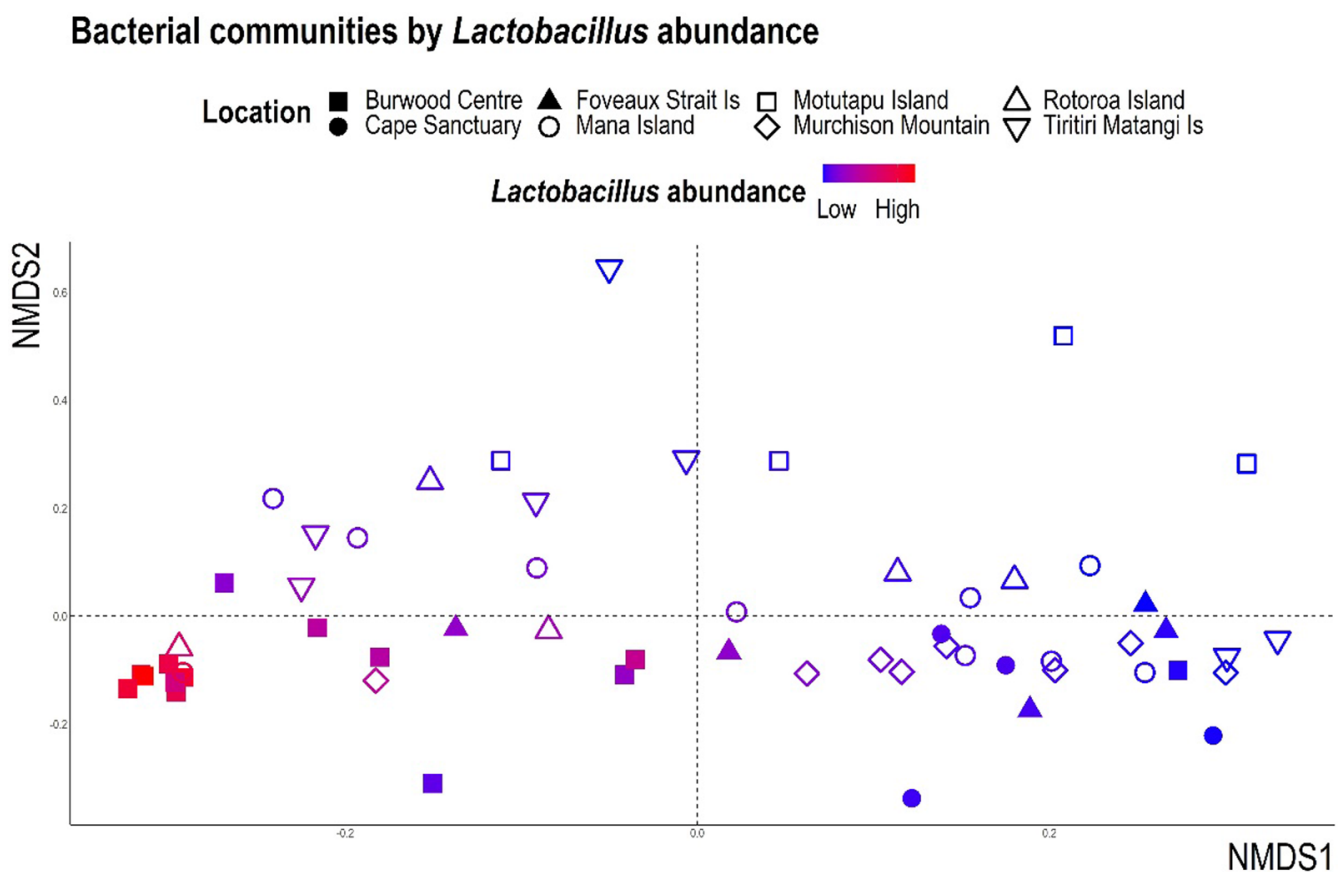

Fig. 2 Bray-Curtis dissimilarity distances visualised via NMDS ordination. Bacterial communities are coloured according to relative Lactobacillus $16 S$ rRNA gene sequence abundance and shaped according to location. Each dot of the NMDS represents a single takahē faecal sample (MDS stress $=0.17)$

variation in faecal bacterial communities; this proportion dropped to $20 \%$ when accounting for differences in supplemental feeding among sites. The first ordination axis separates the takahe faecal communities from Burwood Takahē Centre from those in the Te Puhi-aNoa Murchison Mountains, representing the most- and least-intensively managed takahē populations, respectively (Fig. 2 and Additional file 5: Figure S1). Separation of samples is at least partly attributable to much higher relative sequence abundances of Lactobacillus in the Burwood samples (Fig. 2 and Additional file 5: Figure S1). Pairwise PERMANOVA of both Bray-Curtis and gUniFrac matrices indicated that Burwood Takahē Centre samples were responsible for much of this significant variation (Additional file 5: Table S1). The betadisper test for homogeneity of multivariate dispersions was non-significant for both Bray-Curtis and gUniFrac matrices, indicating that within-group variances were all similar, i.e. all groups showed similar dispersion of samples from their centroid. 
Supplemental feeding alone was significantly associated with microbial beta-diversity ( $p$ value $<0.001$, Table 1) that accounted for $11-13 \%$ of variation among bacterial communities but did not have homogenous group dispersion (Bray-Curtis $p$ value $<0.001, \mathrm{~F}=12.78$; gUniFrac $p$ value $=0.002, \mathrm{~F}=7.57)$. We therefore cannot rule out that the significance of our PERMANOVA test was only due to unequal dispersion within the supplemental feeding groups and not also a result of varying bacterial composition among groups. However, after removing the "Occasional" supplemental feeding group due to small sample size $(n=4)$, both the betadisper and PERMANOVA results remained significant (Bray-Curtis PERMANOVA $p$ value $<0.001, \mathrm{~F}=24.21$ and betadisper $p$ value $=0.001, \mathrm{~F}=4.03$; gUniFrac PERMANOVA $p$ value $=0.002, \mathrm{~F}=4.71$ and betadisper $p$ value $=0.002$, $\mathrm{F}=12.01$ ). All pairwise comparisons were significant, though the comparison between "None" versus "Occasional" supplemental feeding groups yielded a much greater effect size for both Bray-Curtis and gUniFrac matrices than the other two pairwise comparisons (Additional file 5: Table S1). The centroids of the "Regular" and "None" supplemental feeding groups (Additional file 5: Figure S2A) correlate with the Burwood Takahē Centre and Te Puhi-a-Noa Murchison Mountain centroids from the location-based ordinations (Fig. 2 and Additional file 5: Figure S1), suggesting supplemental feeding is likely responsible for some of the observed bacterial variation between the intensively managed Burwood Takahē Centre takahē and the wild Te Puhi-a-Noa Murchison Mountain population. Indeed, sequential PERMANOVA (distance.matrix $\sim$ supplemental feeding + location, by $=$ 'term') and marginal PERMANOVA (distance. matrix $\sim$ supplemental feeding + location, by='margin') indicate that the variation explained by supplemental feeding is captured when testing for location alone and is thus nested inside the variation explained by location. Similarly, the variation among bacterial communities explained by habitat type (Table 1 ) is captured when testing for location effect, yet also has uneven group dispersion (Bray-Curtis $p$ value $=0.006, \mathrm{~F}=8.38$; gUniFrac $p$ value $=0.03, \mathrm{~F}=4.68$ ) (Additional file 5: Figure $\mathrm{S} 2 \mathrm{~B}$ ). Takahē age, sex and rearing method, as well as hatch site and nest site, did not explain a significant proportion of the variation in gut bacterial community composition (significance threshold of $<0.05$; Table 1 ).

Alpha-diversity differed significantly by takahē location with Shannon and Inverse Simpson diversity (Additional file 5: Figure S3A). Supplemental feeding and habitat type also significantly influenced bacterial community Inverse Simpson diversity and observed species richness, respectively (Additional file 5: Figures S3B and $\mathrm{S} 3 \mathrm{C})$. Analyses comparing individual takahē, age or sex did not yield significant differences. Significant Tukey's HSD and Dunn's pairwise comparisons for location and supplemental feeding effects are denoted on Additional file 5: Figures S3A and S3B. There were several instances of significant pairwise comparisons by location across both Shannon and Inverse Simpson diversity indices. However, the small sample size from Cape Sanctuary is likely biasing the significance of comparisons in which this location is included. Overall, faecal samples collected from Burwood Takahē Centre exhibited the lowest bacterial richness and diversity of all eight locations. Additionally, the bacterial communities of faecal samples from takahē experiencing regular supplemental feeding had much lower Inverse Simpson diversity compared to individuals with no supplemental feeding. Faecal samples collected from regenerating habitat had significantly higher bacterial richness than samples collected from established habitats. However, this observation may be driven by the inclusion of six locations in the former compared to two locations in the latter, which includes the low diversity Burwood Takahē Centre samples.

The core microbiota was explored using several different criteria. ASV1, identified as Lactobacillus aviarius, was the only ASV present in all of the faecal samples. Indeed, it was the only ASV present in $\geq 90 \%$ of samples at a threshold of $0.1 \%$ relative sequence abundance. An NCBI nucleotide BLAST search (standard databases and optimised for highly similar sequences) of the ASV1_Lactobacillus aviarius sequence suggests this is a strain of L. aviarius araffinosis (99.30\% sequence identity), a homofermentative, strict anaerobe previously reported from chicken intestines. The mean relative sequence abundance of this ASV across all samples was $17.56 \%(\mathrm{SD}=23.20)$, with a range of $0.01 \%$ to $82 \%$ relative sequence abundance within a given sample. Reducing the core prevalence threshold to $\geq 70 \%$ identified $13 \mathrm{ASVs}$ as core members at a relative sequence abundance threshold of $0.01 \%$ (in order of descending abundance): ASV1_Lactobacillus aviarius, ASV2_Prevotella, ASV3_Fusobacterium mortiferum, ASV4_Clostridium sensu stricto 1, ASV6_Prevotella, ASV12_Lactobacillus aviarius, ASV13_Solobacterium, ASV16_Lactobacillus aviarius, ASV23_Bifidobacterium, ASV24_Lactobacillus, ASV29_Solobacterium, ASV36_Lactobacillus intermedius and ASV83_Lactobacillus aviarius.

Eight genera were identified as comprising the core gut microbiota (defined here as $1 \%$ relative abundance in $75 \%$ of samples): Bacteroides, Bifidobacterium, Campylobacter, Clostridium sensu stricto 1, Lactobacillus, Prevotella, Pseudomonas and Solobacterium (Fig. 3). All genera varied considerably in their relative sequence abundances, both within and between location groupings (Fig. 3). Campylobacter and Pseudomonas were the only genera 


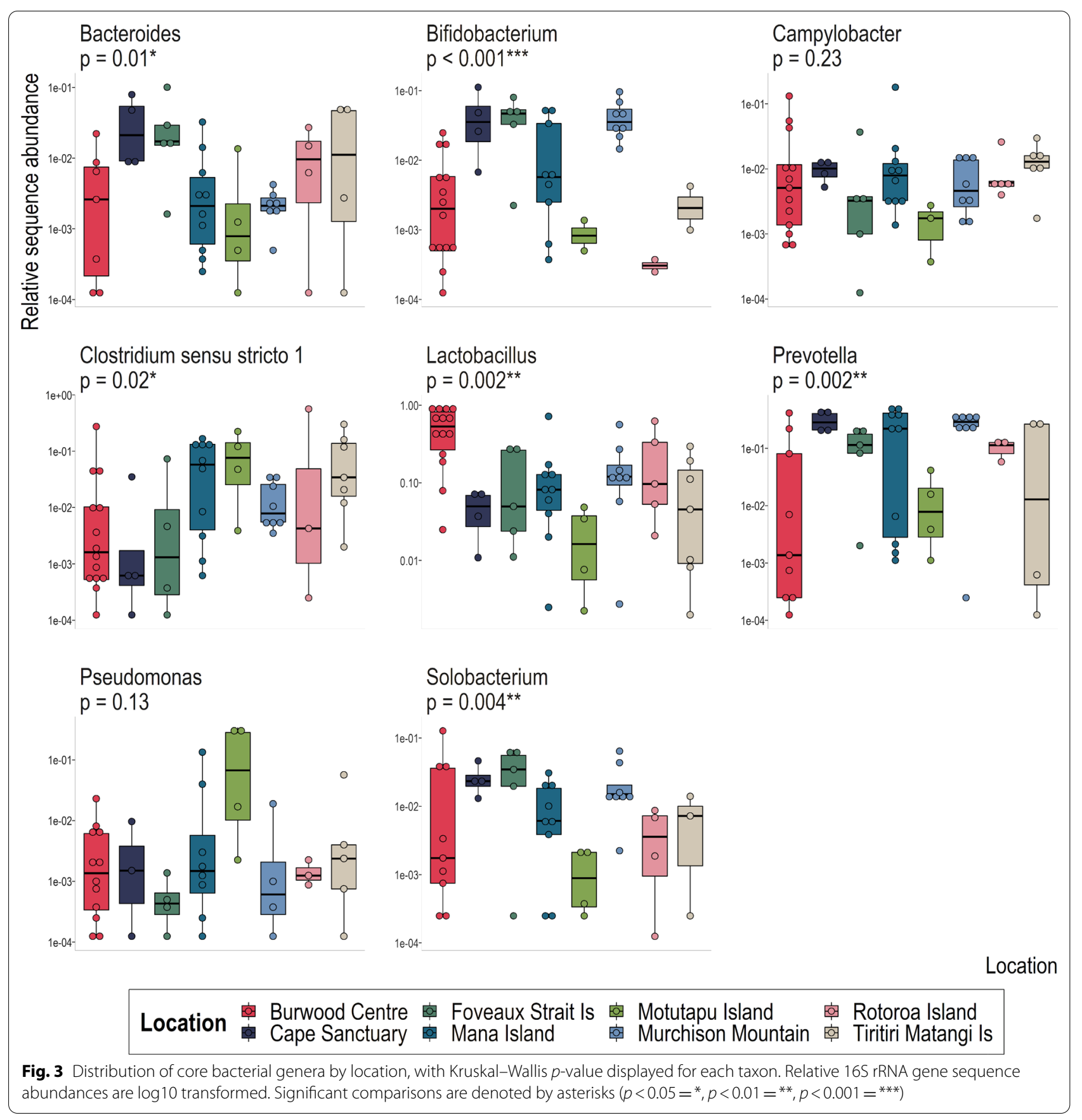

where relative sequence abundance did not differ significantly between locations. The relative sequence abundances of most core genera varied substantially among Burwood Takahē Centre samples, although the relative sequence abundance of Lactobacillus in Burwood Takahē Centre takahē was much greater than was observed in samples from any other location. On the other hand, Prevotella relative sequence abundance was significantly higher in samples from Cape Sanctuary, Foveaux Strait
Island, Te Puhi-a-Noa Murchison Mountain and Rotoroa Island compared to those from Burwood Takahē Centre, Mana Island, Motutapu Island and Tiritiri Matangi Island. The relative sequence abundances of Bifidobacterium and Solobacterium were also significantly greater in Cape Sanctuary, Foveaux Strait Island, Mana Island and Te Puhi-a-Noa Murchison Mountain samples, while samples from Motutapu Island had significantly greater relative sequence abundance of Pseudomonas than any other 


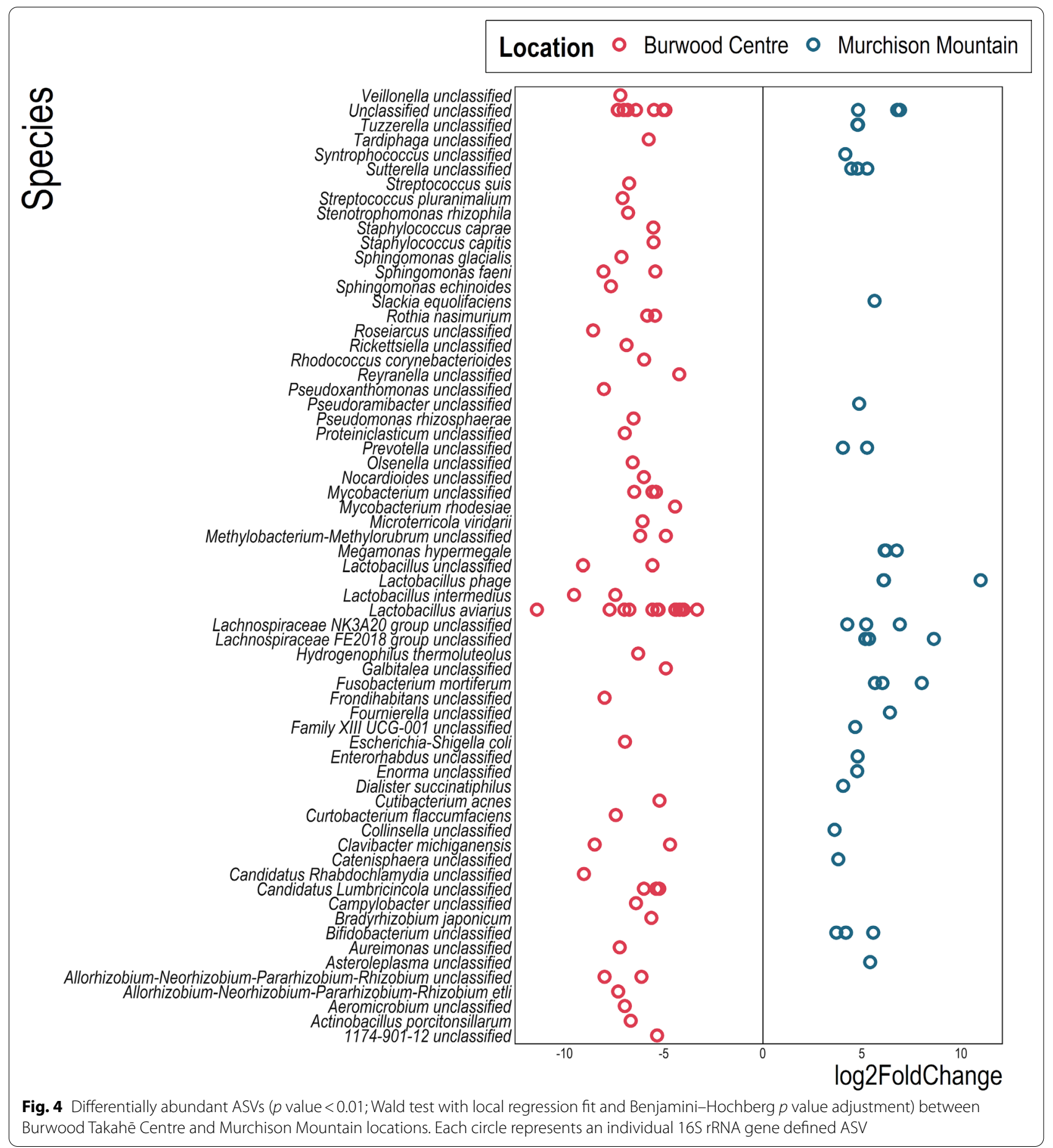

location. Burwood Takahē Centre and Te Puhi-a-Noa Murchison Mountain samples were then isolated to test for differences between captive and wild gut communities at the ASV level.

Differential abundance analysis of ASVs between Burwood Takahē Centre and Te Puhi-a-Noa Murchison
Mountain takahē samples identified 116 ASVs spanning 56 genera and 65 species that significantly differed in relative sequence abundance $(p$ value $<0.01$; Wald test with local regression fit and Benjamini-Hochberg adjustment) between the two locations (Fig. 4). ASV64_Lactobacillus aviarius had 11-fold higher 
abundance in captive Burwood Takahē Centre samples compared to wild Te Puhi-a-Noa Murchison Mountain samples, while core members ASV1_Lactobacillus aviarius, ASV16_Lactobacillus aviarius, ASV36_Lactobacillus intermedius had threefold, fourfold, and 9.5-fold greater relative sequence abundance, respectively, in Burwood Takahē Centre samples. Burwood Takahē Centre samples also hosted several strains of Lactobacillus that were at least fivefold higher in relative sequence abundance compared to Te Puhi-a-Noa Murchison Mountain samples. No L. aviarius, L. intermedius, or unclassified Lactobacillus ASVs were identified as significantly more abundant in the Te Puhi-a-Noa Murchison Mountain samples. However, ASV30_Lactobacillus phage displayed 11-fold higher relative sequence abundance in wild Te Puhia-Noa Murchison Mountain takahē samples, and core member ASV3_Fusobacterium mortiferum had sixfold greater relative sequence abundance.

\section{Discussion}

The takahē is a Nationally Vulnerable [56] rail with $<450$ birds distributed across various sanctuaries and centres throughout Aotearoa New Zealand. Intensive conservation strategies began in 1960 when amateur ornithologist Elwin Welch successfully raised four takahē chicks on his farm near Pūkaha [15]. The Takahē Recovery Programme now supports various scientific research projects to aid their strategies for improving takahē health and reproduction. With microbiota research becoming increasingly popular in the last decade, conservation biology is beginning to incorporate studies on the microbiota of threatened species in an effort to better understand animal biology and health [64, 74]. In Aotearoa New Zealand significant headway has been made in researching the gut microbiota of its only other flightless herbivorous avian species, the critically endangered kākāpō, where a low-diversity microbiota was an unexpected finding in this unique parrot $[67,69,71]$. This paper represents the first study to examine the bacterial microbiota of the takahē gastrointestinal tract and provides evidence for significant compositional differences in microbiota profiles among sampling locations.

\section{The takahē gut microbiota is diverse but frequently dominated by Lactobacillus}

The takahē gut hosts a moderately diverse microbiota that appears to be frequently dominated by members of the Bacteroidota, Firmicutes and Proteobacteria phyla. The most abundant ASV was identified as a strain of Lactobacillus aviarius araffinosis which was present in all birds at an average relative sequence abundance of $17 \%$. In fact, it was the only member of the microbiota to be detected in $>90 \%$ of the sampled population.
Lactobacillus is a commonly described commensal in birds and has been suggested as a probiotic and alternative treatment to antibiotic administration in poultry [35]. L. aviarius araffinosis is a homofermentative bacterium that produces lactic acid from sugar metabolism, and we assume it plays a key role in breaking down plant material ingested by takahē. While Lactobacillus was present in all samples, its relative sequence abundance varied considerably. Location was a significant source of this variation, with samples from Burwood Takahē Centre hosting higher levels of Lactobacillus compared to other sites. Differences in supplementary feeding among sites would not appear to explain the dominance of Lactobacillus in some samples: all birds at Burwood Takahē Centre are supplementary fed yet not all faecal samples from Burwood were dominated by Lactobacillus. However, it likely contributes to the observed variation among bacterial communities. There was a significant difference in the Inverse Simpson diversity measure between samples from takahē which were regularly provided supplementary feed versus those that were not. Regularly fed takahē had lower Inverse Simpson scores, but again this overall significant difference is likely in relation to Lactobacillus dominance in some Burwood Takahē Centre takahē. The collection of more metadata and samples is necessary to tease apart the relationship between Lactobacillus abundance and the takahē gut microbiota.

Other core members of the takahē gut bacterial community identified at $70 \%$ prevalence included members of the two dominant phyla Bacteroidota (Prevotella) and Firmicutes (Lactobacillus aviarius, Lactobacillus intermedius, Lactobacillus sp., Clostridium sensu stricto 1, and Solobacterium), but also included Bifidobacterium (Actinobacteriota) and Fusobacterium mortiferum (Fusobacteriota). Interestingly there were no Proteobacteria ASVs identified as core members of the gut community despite this phylum constituting a large proportion of overall sequence reads. The relative sequence abundances of core genera observed in wild takahē was not markedly different from the patterns observed for insurance population samples. Te Puhi-a-Noa Murchison Mountain samples displayed similar relative sequence abundance of Bifidobacterium, Campylobacter, Lactobacillus, Prevotella, Pseudomonas and Solobacterium to samples from Cape Sanctuary, the Foveaux Strait island, and Mana Island where the habitat differs substantially from the tussock-dominated mountains and is mostly characterised by regenerating native forest and European grasses on formerly-grazed land. Anthropogenic management is reduced on the Foveaux Strait island, but for the population at Cape Sanctuary and Mana Island management practices remain similar to other insurance population 
sites and are considerably greater than the wild population which is largely undisturbed.

The commensal bacterium Campylobacter previously identified in takahē [22, 23] was reasonably prevalent across the current data set and identified as a core genus of the takahe gut microbiota. Grange et al. [23] reported that the prevalence of three Campylobacter species $(C$. sp. nova $1, C$. jejuni, and C. coli) varied among subpopulations in relation to conservation management practices and presence of adjacent farmland. There was also location-associated differentiation of Campylobacter sp. nova 1 genome sequence types [22]. In the current study we identified a strain of Campylobacter jejuni (ASV26) that was detected in $68 \%$ of faecal samples. Grange et al. [23] found $C$. jejuni to be significantly more prevalent in the wild population compared with insurance and captive populations; in the current study C. jejuni had 100\% prevalence at all sites except Burwood Takahē Centre, Tiritiri Matangi Island and Motutapu Island, where the prevalence was $42.9 \%, 42.9 \%$ and $75 \%$, respectively. These conflicting results likely arise from discrepancies between locations sampled in our study versus those of Grange et al. [23], but the overall trend of wild takahē hosting greater prevalence of $C$. jejuni in comparison to the captive Burwood Takahe Centre population is supported by the current study.

\section{Location significantly affects composition of the takahē gut microbiota}

Bacterial composition of the takahē gut varied significantly among sanctuaries, with location explaining $32 \%$ (21\% after accounting for supplemental feeding) of the observed microbiota variation (Fig. 2). Burwood Takahē Centre bacterial communities stood out as having the lowest diversity compared to the other seven locations (Additional file 5: Figure S3). Samples from Burwood Takahē Centre also tended to cluster separately from other samples (Fig. 2), further emphasising the dissimilarity of their communities. This is at least partially driven by the dominance of Lactobacillus in some Burwood Takahē Centre samples, where this genus comprises up to $82 \%$ of obtained $16 \mathrm{~S}$ rRNA gene sequences, and by the relative lack of Prevotella in the majority of Burwood Takahē Centre samples (though this could reflect the compositionality of our 16S rRNA gene sequence data [18, 44, 73]). Te Puhi-a-Noa Murchison Mountain samples appear to host significantly higher relative sequence abundances of ASVs from lineages relating to the fermentation of plant polysaccharides, including Lachnospiraceae, Prevotella, Fusobacterium and Bifidobacterium, possibly indicating greater fermentative potential in the wild takahē gut. Since wild takahē are not provided supplemental feed they may have a greater dependency on gut microbes capable of fermenting plant polysaccharides to obtain their daily energy and nutrient requirements. Te Puhi-a-Noa Murchison Mountain samples also hosted a greater relative sequence abundance of unclassified genera than samples from most other sites, particularly those from Burwood Centre. Supplementary feeding had a significant effect on bacterial community composition but was essentially nested inside location groupings, as evidenced by the centroid locations of 'regular' versus 'no' supplemental feed groups largely overlapping the centroids of Burwood Takahè Centre and Te Puhi-a-Noa Murchison Mountain groups, respectively. It is therefore unclear whether supplementary feeding is actually having a biological effect on the takahē gut microbiota or if some other variable related to these locations is responsible. Established versus regenerating habitat type was also significantly associated with gut microbiota variation, though it had a small effect size and was nested in location groupings. However, this result may only reflect uneven dispersion within the two groups given established habitat was present only at Murchison Mountain and Burwood Takahē Centre. Despite being geographically close, the Burwood Takahē Centre and Te Puhi-a-Noa Murchison Mountain populations, and Motutapu, Rotoroa and Tiritiri Matangi Island populations harbour substantially different gut bacterial communities. Though not directly tested in this study, similar climate conditions do not appear to result in similar gut microbiota profiles for samples from those corresponding sites.

\section{Implications for takahē conservation}

A key motivation for this study was to determine whether aspects of the takahē gut microbiota could be used to inform the conservation and management of this enigmatic species. We were able to identify that takahē from Burwood Takahē Centre hosted far greater relative sequence abundance of Lactobacillus (and corresponding lack of Prevotella species) compared to less intensively managed sites. An obvious point of difference between the captive and wild populations is supplementary feeding with cereal-based pellets. While supplementary feed was identified as a significant factor influencing bacterial community composition, the results are somewhat confounded by the incidence of supplemental feeding at locations categorized by relative captive management in this study. In light of these initial results, we recommend further research should be undertaken to assess potential effects of the cereal pellets' current composition on the takahē gut microbiota. The recent establishment of a second wild takahē population in Kahurangi National Park (and recent translocations to the Te Puhi-a-Noa Murchison Mountains) provides an excellent opportunity 
for such a study to investigate whether supplemental feed is indeed influencing composition of the gut microbiota by increasing sample size and diversity of locations with similar abiotic factors. Altered microbiotas in captivity may have significant impact on subsequent release and restocking efforts [74]. Identifying essential microbes that may be lacking in captive takahē could make good candidates for probiotic supplements to improve translocation success.

Despite captive takahē faecal samples hosting substantially different bacterial communities to those of the wild population, Burwood Takahē Centre takahē are the only external subpopulation in this study to have access to similar tussock habitat as observed for the Te Puhi-a-Noa Murchison Mountain population, albeit with reduced variety. We can only surmise that factors relating to captivity in Burwood Takahē Centre play a much larger role in shaping the gut microbiota than does access to similar wild resources. Captivity significantly alters mammalian gut microbiotas across taxonomically and ecologically diverse species [42]. While the takahē subpopulations are fragmented throughout the country, they are in fact fairly connected via regular translocation networks (described in [21]). As the predominant breeding centre, Burwood Takahē Centre represents the hub of this busy translocation network and thus provides ample opportunity for mixing of microbiotas from various habitat types spanning $>1100 \mathrm{~km}$. Given the potential for a variety of microorganisms to be introduced to the breeding centre during translocation, one might expect to see Burwood Takahē Centre takahē hosting more diverse gut microbiota profiles. Yet Burwood Takahē Centre samples were the least diverse of all eight locations tested and were largely dominated by Lactobacillus, particularly ASV1 Lactobacillus aviarius araffinosis. Though speculative, the high abundance of Lactobacillus in some Burwood Takahē Centre takahē could potentially reflect immunologically naïve systems where Lactobacillus has thrived and dominated other members of the microbiota, especially in younger takahē. Similarly, more frequent medical treatment in a captive environment may also explain why one bacterium tends to dominate the community. Antibiotic treatment can profoundly change both the composition and function of the gut microbiota, and (at least in humans) can even lead to long-lasting effects including the development of autoimmune diseases such as allergies and inflammatory bowel disease [4, 57, 82]. Testing the effect of medical treatment on the takahē gut microbiota is thus another logical future step to better our understanding of external factors that influence gut community composition and function. Shotgun metagenome sequencing would greatly enhance our current knowledge of the gut bacterial community to include not only functional information, but also give valuable insight into the fungal, archaeal, and viral components of the takahe microbiome (defined as the microbiota plus their theatre of activity [7, 38]). Obtaining functional information is essential to the conservation aspect of future projects to understand if altered microbial communities are losing important metabolic functions $[2,9,71]$, or whether variable gut microbiomes perform similar activities regardless of community membership.

The microbiome plays an essential role in development and training of the host immune system [82], notwithstanding its critical role in other aspects of host health (i.e. neurological, digestive, and reproductive systems $[17,41])$. This complex ecosystem of microorganisms is, however, susceptible to external perturbation. The role of anthropogenic disturbance, such as providing medical treatment to threatened species, may have unforeseen consequences on host animal immunity, health, and fitness in relation to altered gut microbial communities $[64,74]$. Conceivably, variation in the takahē gut microbiota could in some instances reflect variable immunological function among sanctuaries. In sites where immunity may be reduced with altered gut microbiota, takahē could be more susceptible to gut pathogens such as coccidia, Salmonella, enteropathogenic Escherichia coli or Erysipelothrix rhusiopathiae, inevitably transmitting these diseases to other subpopulations via translocation. Parasitic larvae are known to alter gut microbial diversity and reduce levels of circulating antibodies in birds [32], leaving them susceptible to further secondary infections. Takahē subpopulations are thought to differ in their tendency to harbour and transmit infectious organisms, based on variable carriage of $C$. coli and $C$. jejuni [23], which could be attributable to altered composition of the gut microbiota. Advancing our knowledge of how the takahē gut microbiome responds and interacts with pathogenic microorganisms can only help to further refine conservation management practices, especially with regard to potential pathogen transmission with translocation.

Our study of the takahē gut microbiota is limited by the absence of a typical control population, as is often the case when working with threatened species. Though we have used samples from the wild Te Puhi-a-Noa Murchison Mountain population to make comparisons with more intensively managed subpopulation microbiota profiles, the takahē rediscovered here only survived European colonisation and subsequent mammalian predation due to the remoteness and harsh climate of this area $[12,28,29,40]$. The population has also been heavily supplemented over time by birds reared at the Takahē Burwood Centre. It is unlikely the current site represents ideal takahē habitat given they were once widespread 
across ecologically diverse habitats in both Te Ika-a-Maui North and Te Waipounamu South Islands of Aotearoa New Zealand [3, 65]. Historically, the takahē gut microbiota may have varied geographically and been functionally flexible depending on available resources in different habitat types. Perhaps the variation of bacterial community composition by location in our current study reflects this speculative hypothesis that takahē have some degree of flexibility in the interactions between microbiota, location, and diet. If so, it would be a promising sign for the conservation management of this unique endemic species.

\section{Concluding remarks}

This study presents a first step towards understanding the role of the gut microbiota in takahe biology and health. Overall, gut microbiota diversity differed among locations and captive individuals hosted much greater relative abundance of Lactobacillus compared to takahē sampled at other sites. We have outlined areas that require further investigation, particularly regarding the collection of extra material and metadata to help facilitate comparisons between gut microbiota samples and perhaps elucidate some of the significant variation between locations observed in this study. This information will help inform the conservation and management of our nationally threatened takahē, and safeguard their survival for future generations.

\section{Supplementary Information}

The online version contains supplementary material available at https://doi. org/10.1186/s42523-021-00158-5. Additional file 1: Metadata collected or available for takahē faecal sam-
ples analysed in this study.

Additional file 2: Taxonomic assignments of amplicon sequence variants (ASVs) obtained from takahē faecal samples.

Additional file 3: Non-rarefied ASV table.

Additional file 4: $R$ markdown file used for statistical analyses of ASV data. Additional file 5: Supplementary tables and figures.

\section{Acknowledgements}

The authors would like to thank the New Zealand Department of Conservation (Te Papa Atawhai) and New Zealand Centre for Conservation Medicine for their help with this study and ongoing interest in microbiome research for endangered species. AW would like to thank Graduate Women New Zealand, the Todd Foundation and the Kate Edger Educational Charitable Trust for their generous scholarships which helped fund this work. We would also like to thank Dr Kevin Chang for his help with statistical aspects of the analysis, and Dr Lara Urban for her insightful comments on the manuscript. The authors wish to acknowledge the use of New Zealand eScience Infrastructure (NeSI) high performance computing facilities, consulting support and training services as part of this research. New Zealand's national facilities are provided by NeSl and funded jointly by NeSl's collaborator institutions and through the Ministry of Business, Innovation \& Employment's Research Infrastructure programme. URL https://www.nesi.org.nz.

\section{Authors' contributions}

AGW analysed and interpreted results and wrote the manuscript. ADeLaunay extracted DNA from the faecal samples and submitted purified PCR products for $16 \mathrm{~S}$ rRNA gene amplicon sequencing. PM collected the majority of takahē faecal samples. EP developed the DNA extraction protocol. MJ helped to collect faecal samples from Burwood Takahē Centre. BG, AP, ADigby and MWT all helped to plan and coordinate the study. All authors read and approved the final manuscript.

\section{Funding}

Waipapa Taumata Rau University of Auckland, New Zealand Department of Conservation (Te Papa Atawhai), Graduate Women New Zealand, the Todd Foundation, and the Kate Edger Educational Charitable Trust.

\section{Availability of data and materials}

The raw sequence data are available in the NCBI SRA repository, under Bioproject accession number PRJNA737580. Metadata, taxonomic assignments, the non-rarefied ASV table and RStudio data analysis have been included as Additional files 1,2, 3 and 4 respectively.

\section{Declarations}

Ethics approval and consent to participate

Samples collected for this study were approved by NZDOC and did not require ethics approval from NZDOC Animal Ethics Committee, which upholds NZDOC's obligations under the New Zealand Animal Welfare Act.

\section{Consent for publication}

Not applicable.

\section{Competing interests}

The authors declare that they have no competing interests.

\section{Author details}

${ }^{1}$ School of Biological Sciences, University of Auckland, Private Bag 92019, Auckland 1142, New Zealand. ${ }^{2}$ Takahē Recovery Programme, Department of Conservation, Lakefront Drive, Te Anau, New Zealand. ${ }^{3}$ School of Veterinary Science, Massey University, Palmerston North, New Zealand. ${ }^{4}$ New Zealand Centre for Conservation Medicine, Auckland Zoo, Auckland, New Zealand. ${ }^{5}$ Present Address: Division of Biology and Biological Engineering, California Institute of Technology, Pasadena, CA, USA.

Received: 23 June 2021 Accepted: 22 December 2021

Published online: 25 January 2022

\section{References}

1. Amato KR, Metcalf JL, Song SJ, Hale VL, Clayton J, Ackermann G, Humphrey $G$, et al. Using the gut microbiota as a novel tool for examining colobine primate Gl health. Glob Ecol Conserv. 2016;7:225-37. https:// doi.org/10.1016/j.gecco.2016.06.004.

2. Amato KR, Yeoman CJ, Kent A, Righini N, Carbonero F, Estrada A, Gaskins $H R$, et al. Habitat degradation impacts black howler monkey (Alouatta pigra) gastrointestinal microbiomes. ISME J. 2013;7(7):1344. https://doi. org/10.1038/ismej.2013.16.

3. Baber MJ, Craig JL. The relationship between foraging behaviour and habitat use by South Island takahe (Porphyrio hochstetteri) on Tiritiri Matangi Island. Notornis. 2003;50:59-66.

4. Becattini S, Taur Y, Pamer EG. Antibiotic-induced changes in the intestinal microbiota and disease. Trends Mol Med. 2016;22(6):458-78. https://doi. org/10.1016/j.molmed.2016.04.003.

5. Becker AAMJ, Harrison SWR, Whitehouse-Tedd G, Budd JA, WhitehouseTedd KM. Integrating gut bacterial diversity and captive husbandry to optimize vulture conservation. Front Microbiol. 2020;11:1025. https://doi. org/10.3389/fmicb.2020.01025.

6. Benjamini Y, Hochberg Y. Controlling the false discovery rate: A practical and powerful approach to multiple testing. J Royal Stat Soc: Ser B (Methodol) 1995;57:289-300. https://doi.org/10.1111/j.2517-6161.1995.tb020 31.x. 
7. Berg G, Rybakova D, Fischer D, Cernava T, Vergès M-CC, Charles T, Chen X, Cocolin L, Eversole K, Corral GH, Kazou M, Kinkel L, Lange L, Lima N, Loy A, Macklin JA, Maguin E, Mauchline T, McClure R, Mitter B, Ryan M, Sarand I, Smidt H, Schelkle B, Roume H, Kiran GS, Selvin J, de Souza RSC, van Overbeek L, Singh BK, Wagner M, Walsh A, Sessitsch A, Schloter M. Microbiome definition re-visited: old concepts and new challenges. Microbiome. 2020;8(1):103. https://doi.org/10.1186/s40168-020-00875-0.

8. Bodkhe R, Shetty SA, Dhotre DP, Verma AK, Bhatia K, Mishra A, Kaur G, et al. Comparison of small gut and whole gut microbiota of first-degree relatives with adult celiac disease patients and controls. Front Microbiol. 2019;10:164. https://doi.org/10.3389/fmicb.2019.00164.

9. Borbón-García A, Reyes A, Vives-Flórez M, Caballero S. Captivity Shapes the gut microbiota of andean bears: insights into health surveillance. Front Microbiol. 2017;8:1316. https://doi.org/10.3389/fmicb.2017.01316.

10. Callahan BJ, McMurdie PJ, Rosen MJ, Han AW, Johnson AJA, Holmes SP. DADA2: High-resolution sample inference from Illumina amplicon data. Nat Methods. 2016. https://doi.org/10.1038/nmeth.3869.

11. Chen, J. 2018. Generalized UniFrac Distances. https://CRAN.R-project.org/ package $=$ GUniFrac

12. Clout MN, Craig JL. The conservation of critically endangered flightless birds in New Zealand. Ibis. 1995;137(s1):S181-90. https://doi.org/10. 1111/j.1474-919x.1995.tb08440.x.

13. Crouchley D. Takahe Recovery Plan (Porphyrio [Notornis] Mantelli). Threatened Species Recovery Plan No.12. Wellington, New Zealand: Threatened Species Unit, Department of Conservation. 1994

14. Dinno A. dunn.test: Dunn's Test of Multiple Comparisons Using Rank Sums. 2017. https://CRAN.R-project.org/package $=$ dunn.test

15. Eason DK, Willams M. Captive rearing: a management tool for the recovery of the endangered takahe. In: Lee WG, Jamieson IG, editors. The Takahe: fifty years of conservation management and research. Dunedin, New Zealand: University of Otago Press; 2001. p. 80-95.

16. Garcia-Amado MA, Michelangeli F, Gueneau P, Perez ME, DominguezBello MG. Bacterial detoxification of saponins in the crop of the avian foregut fermenter Opisthocomus hoazin. J Anim Feed Sci. 2007;16:82-5.

17. Gilbert JA, Blaser MJ, Caporaso JG, Jansson JK, Lynch SV, Knight R. Current understanding of the human microbiome. Nat Med. 2018;24(4):392-400. https://doi.org/10.1038/nm.4517.

18. Gloor GB, Macklaim JM, Pawlowsky-Glahn V, Egozcue JJ. Microbiome datasets are compositional: and this is not optional. Front Microbiol. 2017;8:2224. https://doi.org/10.3389/fmicb.2017.02224

19. Godoy-Vitorino F, Ley RE, Gao Z, Pei Z, Ortiz-Zuazaga H, Pericchi LR, Garcia-Amado MA, et al. Bacterial community in the crop of the hoatzin, a neotropical folivorous flying bird. Appl Environ Microbiol. 2008;74(19):5905-12. https://doi.org/10.1128/aem.00574-08.

20. Grajal A, Strahl SD, Parra R, Dominguez MG, Neher A. Foregut fermentation in the hoatzin, a neotropical leaf-eating bird. Science. 1989;245(4923):1236-8. https://doi.org/10.1126/science.245.4923.1236.

21. Grange ZL, Andel MV, French NP, Gartrell BD. Network analysis of translocated takahe populations to identify disease surveillance targets. Conserv Biol. 2014;28(2):518-28. https://doi.org/10.1111/cobi.12178.

22. Grange ZL, Gartrell BD, Biggs PJ, Nelson NJ, Anderson M, French NP. Microbial genomics of a host-associated commensal bacterium in fragmented populations of endangered takahe. Microb Ecol. 2015;71(4):1020-9. https://doi.org/10.1007/s00248-015-0721-5.

23. Grange ZL, Gartrell BD, Biggs PJ, Nelson NJ, Marshall JC, Howe L, Balm MGM, French NP. Using a common commensal bacterium in endangered takahe as a model to explore pathogen dynamics in Isolated Wildlife Populations. Conserv Biol. 2015;29(5):1327-36. https://doi.org/10.1111/ cobi.12521.

24. Grond K, Sandercock BK, Jumpponen A, Zeglin LH. The avian gut microbiota: community, physiology and function in wild birds. J Avian Biol. 2018:49(11): e01788. https://doi.org/10.1111/jav.01788.

25. Grueber CE, Jamieson IG. Low genetic diversity and small population size of Takahe Porphyrio hochstetteri on European arrival in New Zealand: Historical genetic diversity of Takahe. Ibis. 2011;153(2):384-94. https://doi. org/10.1111/j.1474-919x.2011.01110.x.

26. Hall $A B$, Tolonen $A C$, Xavier RJ. Human genetic variation and the gut microbiome in disease. Nat Rev Genet. 2017;18(11):690-9. https://doi. org/10.1038/nrg.2017.63.

27. Hansford D. Road to recovery. National Geographic 156 2019. https:// www.nzgeo.com/stories/road-to-recovery/.
28. Hegg D, Greaves G, Maxwell JM, MacKenzie DI, Jamieson IG. Demography of takahe (Porphyrio hochstetteri) in Fiordland: environmental factors and management affect survival and breeding success. N Z J Ecol. 2012;36(1):75-89.

29. Hegg D, MacKenzie DI, Jamieson IG. Use of Bayesian population viability analysis to assess multiple management decisions in the recovery programme for the endangered takahe Porphyrio hochstetteri. Oryx. 2013;47(1):144-52. https://doi.org/10.1017/s0030605311001736.

30. Hobson P. Introduction. In: Hobson P, Stewart C, editors. The rumen microbial ecosystem. Dordrecht: Springer; 1997. p. 1-9.

31. Kassambara, A. 2020. ggpubr:'ggplotz' based publication ready plots. $R$ package version 0.4.0

32. Knutie SA. Relationships among introduced parasites, host defenses, and gut microbiota of Galapagos birds. Ecosphere. 2018;9(5):e02286. https:// doi.org/10.1002/ecs2.2286.

33. Lahti L, Shetty S, et al. Tools for microbiome analysis in R. Version 1.13.9. 2017. http://microbiome.github.com/microbiome

34. Lee WG, Jamieson IG. Introduction. In: Lee WG, Jamieson IG, editors. The Takahe: fifty years of conservation management and research. Dunedin: University of Otago Press; 2001. p. 11-7.

35. Li Z, Wang W, Liu D, Guo Y. Effects of Lactobacillus acidophilus on the growth performance and intestinal health of broilers challenged with Clostridium perfringens. J Anim Sci Biotechnol. 2018;9(1):25. https://doi. org/10.1186/s40104-018-0243-3.

36. Love Ml, Huber W, Anders S. Moderated estimation of fold change and dispersion for RNA-seq data with DESeq2. Genome Biol. 2014;15(12):550. https://doi.org/10.1186/s13059-014-0550-8.

37. Mackie RI. Mutualistic Fermentative Digestion in the Gastrointestinal Tract: Diversity and Evolution. Integr Comp Biol. 2002;42(2):319-26. https://doi.org/10.1093/icb/42.2.319.

38. Marchesi JR, Ravel J. The vocabulary of microbiome research: A proposal. Microbiome. 2015;3(1):31. https://doi.org/10.1186/s40168-015-0094-5.

39. Martinez Arbizu P. pairwiseAdonis: Pairwise multilevel comparison using adonis. 2020.

40. Maxwell JM. Fiordland takahe: population trends, dynamics and problems. In: Lee WG, Jamieson IG, editors. The Takahe: Fifty Years of Conservation Management and Research. Dunedin: University of Otago Press; 2001. p. 61-79.

41. McKenney EA, Koelle K, Dunn RR, Yoder AD. The ecosystem services of animal microbiomes. Mol Ecol. 2018;27:2164-72. https://doi.org/10.1111/ mec.14532.

42. McKenzie VJ, Song SJ, Delsuc F, Prest TL, Oliverio AM, Korpita TM, et al. The effects of captivity on the mammalian gut microbiome. Integr Comp Biol. 2017;57(4):690-704. https://doi.org/10.1093/icb/icx090.

43. McMurdie PJ, Holmes S. phyloseq: An R Package for Reproducible Interactive Analysis and Graphics of Microbiome Census Data. PLOS ONE. 2013;8(4): e61217. https://doi.org/10.1371/journal.pone.0061217.

44. McMurdie PJ, Holmes S. Waste not, want not: Why rarefying microbiome data is inadmissible. PLoS Comput Biol. 2014;10(4): e1003531. https://doi. org/10.1371/journal.pcbi.1003531.

45. Mills JA., Lavers RB, Lee WG. The Takahè - A Relict of the Pleistocene Grassland Avifauna of New Zealand. New Zealand J Ecol. 1984;7:57-70.

46. Mills JA, Lee WG, Lavers RB. Experimental Investigations of the Effects of Takahe and Deer Grazing on Chionochloa pallens Grassland, Fiordland, New Zealand. The Journal of Applied Ecology. 1989;26(2):397. https://doi. org/10.2307/2404069.

47. Mills JA, Lee WG, Mark AF, Lavers RB. Winter use by takahe (Notornis mantelli) of the summer-green fern (Hypolepis millefolium) in relation to its annual cycle of carbohydrates and minerals. N Z J Ecol. 1980;3:131-7.

48. Oksanen J, Blanchet FG, Friendly M, Kindt R, Legendre P, McGlinn D, Minchin PR, O'Hara RB, Simpson GL, Solymos P, Stevens MHH, Szoecs E, Wagner H. vegan: Community Ecology Package. R package version 2.5-7. 2020. https://CRAN.R-project.org/package=vegan

49. Perry EK, Digby A, Taylor MW. The Low-Diversity Fecal Microbiota of the Critically Endangered Kākāpō Is Robust to Anthropogenic Dietary and Geographic Influences. Front Microbiol. 2017;8:2033. https://doi.org/10. 3389/fmicb.2017.02033.

50. Quast C, Pruesse A, Yilmaz P, Gerken J, Schweer T, Yarza P, Peplies J, Glöckner FO. The SILVA ribosomal RNA gene database project: improved data processing and web-based tools. Nucleic Acids Res. 2013;41(D1):D590-6. 
51. R Core Team. 2019. R: A language and environment for statistical computing. Vienna, Austria: R Foundation for Statistical Computing. https:// www.R-project.org/.

52. R Core Team. 2021. R: A language and environment for statistical computing. Vienna, Austria: R Foundation for Statistical Computing. https:// www.R-project.org/.

53. Ram K, Wickham H, Richards C, Baggett A. A Wes Anderson Palette Generator. 2018. https://github.com/karthik/wesanderson

54. Reid B. Sightings and Records of the Takahe (Notornis mantelli) Prior to its "Official Rediscovery" by DR G. B. Orbell in 1948. Notornis 1974a;21(4): 77-95.

55. Reid B. Faeces of takahe (Notornis mantelli): A general discussion relating the quantity of faeces to the type of food and to the estimated energy requirements of the bird. Notornis. 1974;21(4):306-11.

56. Robertson HA, Baird K, Dowding JE, Elliott GP, Hitchmough RA, Miskelly CM, McArthur N, O'Donnell CFJ, Sagar PM, Scofield RP, Taylor GA. Conservation status of New Zealand birds. 2016. New Zealand Threat Classification Series 19. Wellington, New Zealand: Department of Conservation.

57. Russell SL, Gold MJ, Hartmann M, Willing BP, Thorson L, Wlodarska M, Gill N, Blanchet M-R, Mohn WW, McNagny KM, Finlay BB. Early life antibioticdriven changes in microbiota enhance susceptibility to allergic asthma. EMBO Rep. 2012;13:440-7. https://doi.org/10.1038/embor.2012.32.

58. Schliep KP. phangorn: phylogenetic analysis in R. Bioinformatics. 2011:27(4):592-3.

59. Song S, Amir A, Metcalf J, Amato K, Xu Z, Humphrey G, Knight R. Preservation methods differ in fecal microbiome stability, affecting suitability for field studies. mSystems. 2016. https://doi.org/10.1128/mSystems. 00021-16.

60. Spergser J, Loncaric I, Tichy A, Fritz J, Scope A. The cultivable autochthonous microbiota of the critically endangered Northern bald ibis (Geronticus eremita). PLoS ONE. 2018;13(4):e0195255. https://doi.org/10. 1371/journal.pone.0195255.

61. Spor A, Koren O, Ley R. Unravelling the effects of the environment and host genotype on the gut microbiome. Nat Rev Microbiol. 2011;9(4):279_ 90. https://doi.org/10.1038/nrmicro2540.

62. Suttie JM, Fennessy PF. Organ Weight and Weight Relationships in Takahe and Pukeko. Notornis. 1992;49:47-53.

63. Thomson G. 2020. NZ Bird Colour Palettes. https://github.com/G-Thoms on/Manu

64. Trevelline BK, Fontaine SS, Hartup BK, Kohl KD. Conservation biology needs a microbial renaissance: a call for the consideration of host-associated microbiota in wildlife management practices. Proc R Soc B: Biol Sci. 2019;286(1895):2018-448. https://doi.org/10.1098/rspb.2018.2448.

65. Trewick SA, Worthy TH. Origins and prehistoric ecology of takahe based on morphometric, molecular and fossil data. In: Lee WG, Jamieson IG, editors. The Takahe: fifty years of conservation management and research. Dunedin: University of Otago Press; 2001. p. 23-30.

66. Videvall E, Strandh M, Engelbrecht A, Cloete S, Cornwallis CK. Measuring the gut microbiome in birds: Comparison of faecal and cloacal sampling. Mol Ecol Resour. 2018;18(3):424-34. https://doi.org/10.1111/1755-0998. 12744.

67. Waite DW, Deines P, Taylor MW. Gut Microbiome of the Critically Endangered New Zealand Parrot, the Kakapo (Strigops habroptilus). PLoS ONE. 2012;7(4): e35803. https://doi.org/10.1371/journal.pone.0035803.

68. Waite DW, Taylor MW. Characterizing the avian gut microbiota: membership, driving influences, and potential function. Front Microbiol. 2014;5:223. https://doi.org/10.3389/fmicb.2014.00223.

69. Waite DW, Eason DK, Taylor MW. Influence of hand rearing and bird age on the fecal microbiota of the critically endangered kakapo. Appl Environ Microbiol. 2014;80(15):4650-8. https://doi.org/10.1128/AEM.00975-14.

70. Waite DW, Taylor MW. Exploring the avian gut microbiota: current trends and future directions. Front Microbiol. 2015;6:673. https://doi.org/10. 3389/fmicb.2015.00673.

71. Waite DW, Dsouza M, Sekiguchi Y, Hugenholtz P, Taylor MW. Networkguided genomic and metagenomic analysis of the faecal microbiota of the critically endangered kakapo. Sci Rep. 2018;8(1):8128. https://doi.org/ 10.1038/s41598-018-26484-4.

72. Wang B, Yao M, Lv L, Ling Z, Li L. The human microbiota in health and disease. Engineering. 2017;3(1):71-82. https://doi.org/10.1016/j.eng.2017. 01.008 .
73. Weiss S, Xu ZZ, Peddada S, Amir A, Bittinger K, Gonzalez A, Lozupone $C$, et al. Normalization and microbial differential abundance strategies depend upon data characteristics. Microbiome. 2017;5(1):27. https://doi. org/10.1186/s40168-017-0237-y.

74. West AG, Waite DW, Deines P, Bourne DG, Digby A, McKenzie VJ, Taylor $\mathrm{MW}$. The microbiome in threatened species conservation. Biol Cons. 2019;229:85-98. https://doi.org/10.1016/j.biocon.2018.11.016.

75. Wickham H. The split-apply-combine strategy for data analysis. J Stat Software. 2011;40(1):1-29.

76. Wickes C, Crouchley D, Maxwell J. Takahe (Porphyrio hochstetteri) recovery plan: 2007-2012. Threatened Species Recovery Plan No. 61. Wellington, New Zealand: Threatened Species Unit, Department of Conservation. 2009.

77. Wickham H. ggplot2: Elegant graphics for data analysis. New York, NY: Springer-Verlag; 2016

78. Wilke CO. cowplot: Streamlined plot theme and plot annotations for 'ggplot2'. 2020. https://CRAN.R-project.org/package=cowplot.

79. Williams GR. The takahe (Notornis mantelli Owen, 1848): a general survey. Trans R Soc New Zeal. 1960;88:235-58.

80. Wright ES. Using DECIPHER v2.0 to analyze big biological sequence data in R. R J. 2016;8(1):352-9.

81. Xiao N, Cook J, Li M. 2018. ggsci: Scientific Journal and Sci-Fi Themed Color Palettes for 'ggplot2.' https://CRAN.R-project.org/package=ggsci

82. Zheng D, Liwinski T, Elinav E. Interaction between microbiota and immunity in health and disease. Cell Res. 2020;30:492-506. https://doi.org/10. 1038/s41422-020-0332-7.

\section{Publisher's Note}

Springer Nature remains neutral with regard to jurisdictional claims in published maps and institutional affiliations.

Ready to submit your research? Choose BMC and benefit from

- fast, convenient online submission

- thorough peer review by experienced researchers in your field

- rapid publication on acceptance

- support for research data, including large and complex data types

- gold Open Access which fosters wider collaboration and increased citations

- maximum visibility for your research: over $100 \mathrm{M}$ website views per year

At BMC, research is always in progress.

Learn more biomedcentral.com/submissions 